\title{
EFFICACY OF ORALLY ADMINISTERED IVERMECTIN AGAINST LARVAL STAGES OF BOT FLY (Cephenemyia stimulator C.) IN ROE DEER
}

\author{
J. LAMKA, J. SUCHÝ, F. ŠTAUD
}

Department of Pharmacology and Toxicology, Faculty of Pharmacy, Charles University, Hradec Králové

Received November 30, 1995

Accepted February 10, 1997

\begin{abstract}
Lamka J., J. Suchý, F. Štaud: Efficacy of Orally Administered Ivermectin Against Larial Stages of Bot Fly (Cephenemyia stimulator C.) in Roe Deer. Acta vet. Brno, 1997, 66: 51 - 55.

The aim of this study was to determine the efficacy of a two-day winter administration of ivermectin ( $0.30 \mathrm{mg} . \mathrm{kg}^{-1}$ body mass per day) against larval stages of Cephenemyia stimulator $\mathrm{C}$. in roe deer. The study consisted of two phases: one 3-year and two 1.5-year periods. The numbers of larvae in roebuck, doe and roe kid heads (a total of 283 animals) were determined. The prevalence and intensity of infestation before and after ivermectin administration were calculated. It was demonstrated that the drug reduces markedly spring and summer values of prevalence as well as intensity of infestation. However, after the summer period, prevalence and intensity of infestation began to rise conspicuously again. Biological properties of the causative agent of this parasitosis call for annual treatment of game in independent hunting grounds or their smaller complexes.
\end{abstract}

Ivermectin, hoofed game, ectoparasitosis

Both bot and warble fly diseases of roe deer are the most important among ectoparasitoses of hoofed game in the Czech Republic. So far, only rafoxanide has been successfully used in the treatment of bot fly disease (Ševčík et al. 1986) whereas warble fly larvae are sensitive neither to this nor any other drug that can be simultaneously administered to large numbers of game.

After good tolerance of orally administered ivermectin (IVM) was found in hoofed game and after comprehensive studies of its anthelmintic effects, also an effect against game ectoparasitoses in our laboratory was studied. Very good results regarding use of IVM administered parenterally and orally to domestic animals (horse, pig) in ectoparasitic indications were obtained (Campbell 1989).

Our experiments were aimed to describe IVM efficacy in mass oral administration against larval stages of bot fly disease in roe deer.

\section{Materials and Methods}

\section{Localities}

The territory of 6 hunting grounds was connected for the purpose of our study (Nový Hradec Králové, Býšt, Vysoká, Běleč, Městské lesy Hradec Králové a Lesy ČR) in the Hradec Králové District. Czech Republic. The area was named Hradecko (total area of 7845 ha). Furthemore, studies were carried out in independent hunting grounds Luže (Chrudim District, 3850 ha) and Blešno (Hradec Králové District, 12.10 ha).

\section{IVM administration}

Premix of the drug (Cermix premix, Biopharm, Jílové u Prahy) was centrally mixed into each of all grain meals for use in all hunting grounds, and the resultant medicated feed was distributed in feeding places by forestry workers according to actual numbers of animals. The consumption of medicated feed was checked and evaluated in each hunting ground.

The drug was administered to game for two subsequent days in the period of winter supplementary feeding at a dose of $0.30 \mathrm{mg} . \mathrm{kg}$ body mass and day. Before administration, a preparatory phase was included during which supplementary feeding of attractive feeds was carried out. At the same time, concentration of game at feeding places and numbers and species of game were recorded. 
Parasitological examinations

Numbers of bot fly larvae (Cephenemyia stimulator C.) were determined in shot roebucks during trophy processing in hunting grounds in the period of May 16 to July 31 annually. This major spring and summer period of study was supplemented by examinations of does and roe kids in the period from September 1 to December 31 performed (autumn period) in our laboratory. Examinations were carried out via rinsing of nasal cavities, sedimentation of rinses and their quantitative evaluation for the presence of young larval stages of bot fly. The control group was obtained through the examination of heads of doe and roe kids from hunting grounds on Hradec Králové District, where IVM treatment waas not carried out.

In the course of the whole period of study, supervisors of individual hunting grounds kept detailed records according to a uniform method and these were submitted to principal investigator at the Faculty of Pharmacy for evaluation. Basic parameters were determined such as prevalence (percentage of incidence out of animals of game studied) and intensity of infestation (II) (number of larvae/positive head of game).

\section{Results}

\section{1) Hradecko}

A total of 113 heads of shot roebucks was checked in 1992-94 (Table 1) from initiation till termination of the study. Spring and summer prevalence in roebucks ranged between 23.1 and $26.7 \%$, the average II ranging between 9.3 and 10.6 larvae. In 1993, during the autumn hunting season, for the first time also examinations of doe and roe kids were carried out. The prevalence achieved as much as $50.0 \%$ and $72.5 \%$ in the first and second year, respectively. The average II amounted to 10.5 and 12.9 larvae, respectively.

Table 1

Bot fly disease in roebucks, does and roe kids - hunting grounds of Hradecko 1992 - 1994

\begin{tabular}{|c|c|c|c||c|c|c|c|}
\hline \multirow{2}{*}{$\begin{array}{c}\text { Year } \\
\text { of study }\end{array}$} & \multicolumn{3}{|c||}{ Roebucks } & \multicolumn{3}{|c|}{ Does and roe kids } & \multirow{2}{*}{ Note } \\
\cline { 2 - 7 } & heads & $\begin{array}{c}\text { Prevalence } \\
\text { (\%) }\end{array}$ & $\begin{array}{c}\text { II } \\
\text { (Mean of } \\
\text { larvae/head) }\end{array}$ & $\begin{array}{c}\text { Examined } \\
\text { heads }\end{array}$ & $\begin{array}{c}\text { Prevalence } \\
\text { (\%) }\end{array}$ & $\begin{array}{c}\text { II } \\
\text { (Mean of } \\
\text { larvae/head) }\end{array}$ & \\
\hline 1991 & & $20-90$ & & & - & & $\begin{array}{c}\text { State before } \\
\text { initiation } \\
\text { of study }\end{array}$ \\
\hline 1992 & 39 & 23.1 & 10.5 & - & - & - & \\
\hline 1993 & 30 & 26.7 & 10.6 & 22 & 50.0 & 10.5 & \\
\hline 1994 & 44 & 25.0 & 9.3 & 40 & 72.5 & 12.9 & \\
\hline
\end{tabular}

II - Intensity of infestation

\section{2) Hunting grounds Luže and Blešno}

In the hunting grounds Luže in 1994 and 1995, the spring and summer infestation prevalence in roebucks achieved the following values: $29.4 \%$ and $25.0 \%$, respectively (Table 2), the corresponding values for the same years in the hunting ground Blešno being $10.0 \%$ and $0.0 \%$, respectively (Table 3 ). Mean II values in individual years in both hunting grounds were very low ranging between 0 and 4 larvae. In the autumn examinations (1994), doe and roe kid infestation prevalence in both grounds was as high as $68.8 \%$ (Luže) and $85.7 \%$ (Blešno). The corresponding mean II values amounted to 12.0 and 10.3 larvae, respectively.

\section{3) Control group}

In the control group ( 35 heads, 1994), the autumn prevalence amounted to $65.7 \%$ with the 
Table 2

Bot fly disease in roebucks, does and roe kids - hunting ground of Luže 1994 - 1995

\begin{tabular}{|c|c|c|c|c|c|c|c|}
\hline \multirow[b]{2}{*}{$\begin{array}{c}\text { Year } \\
\text { of study }\end{array}$} & \multicolumn{3}{|c|}{ Roebucks } & \multicolumn{3}{|c|}{ Does and roe kids } & \multirow[b]{2}{*}{ Note } \\
\hline & $\begin{array}{l}\text { Examined } \\
\text { heads }\end{array}$ & $\begin{array}{c}\text { Prevalence } \\
(\%)\end{array}$ & $\begin{array}{c}\text { II } \\
\text { (Mean of } \\
\text { larvae/head) }\end{array}$ & $\begin{array}{l}\text { Examined } \\
\text { heads }\end{array}$ & $\begin{array}{c}\text { Prevalence } \\
(\%)\end{array}$ & $\begin{array}{c}\text { II } \\
\text { (Mean of } \\
\text { larvae/head) }\end{array}$ & \\
\hline 1992 & & 60.0 & & & & & $\begin{array}{l}\text { High prevalence } \\
\text { with frequent } \\
\text { severe infestation }\end{array}$ \\
\hline 1993 & 17 & 29.4 & 4.0 & 16 & 68.8 & 12.0 & \\
\hline 1994 & 16 & 25.0 & 2.8 & - & - & - & \\
\hline
\end{tabular}

II - Intensity of infestation

mean finding of infestation intensity 14.2 larvae.

\section{Discussion}

Present infestation of roe deer in the Czech Republic by both bot and warble flies is very high. This results in weak to very weak individuals in terms of body mass and general health condition. In severe cases there are death losses, disability to produce top quality trophies, and also impaired foetal development can be encountered. Often culling of diseased game is necessary. In general, both ectoparasitoses cause high losses in roe deer populations. Their limitation or eradication can only be achieved at present by control of the development of larval stages of both parasite species. In terms of pharmacotherapeutic intervention, it is convenient that the biological cycle of both species takes place as a parallel infestation. This fact provides an opportunity to address the problem simultaneously (provided there is a sufficient susceptibility of larvae of both fly species to the same drug).

Table 3

Bot fly disease in roebucks, does and roe kids - hunting ground of Blešno 1994 - 1995

\begin{tabular}{|c|c|c|c|c|c|c|c|}
\hline \multirow[b]{2}{*}{$\begin{array}{l}\text { Year } \\
\text { of study }\end{array}$} & \multicolumn{3}{|c|}{ Roebucks } & \multicolumn{3}{|c|}{ Doe and roe kids } & \multirow[b]{2}{*}{ Note } \\
\hline & $\begin{array}{l}\text { Examined } \\
\text { heads }\end{array}$ & $\begin{array}{c}\text { Prevalence } \\
\text { (\%) }\end{array}$ & $\begin{array}{c}\text { II } \\
\text { (Mean of } \\
\text { larvae/head) }\end{array}$ & $\begin{array}{l}\text { Examined } \\
\text { heads }\end{array}$ & $\begin{array}{c}\text { Prevalence } \\
(\%)\end{array}$ & $\begin{array}{c}\text { II } \\
\text { (Mean of } \\
\text { larvae/head) }\end{array}$ & \\
\hline 1993 & & 75.0 & & & - & & $\begin{array}{l}\text { High prevalence } \\
\text { with frequent } \\
\text { severe infestation }\end{array}$ \\
\hline 1994 & 10 & 10.0 & 3.0 & 7 & 85.7 & 10.3 & \\
\hline 1995 & 7 & 0.0 & 0.0 & - & - & - & \\
\hline
\end{tabular}

II - Intensity of infestation

Determined or estimated prevalence of bot fly disease of roe deer in the area Hradecko ranged between 20 and $90 \%$ prior to initiation of our IVM study. The low value (20\%) refers to the only one hunting ground (where already in preceding years an intensive study of the effects of rafoxanide as well as of IVM had been carried out), in the remaining ones, the prevalence ranged between 70 and $90 \%$. Already the first administration of the drug in 1992 managed to reduce the spring and summer prevalence to $23.1 \%$. This value was maintained with only a slight 
transient increase until termination of the study in 1994. Mean infestation intensity was ca 10 larvae for the entire period under study. However, even despite a conspicious reduction of prevalence values in the spring and summer, the results of autumn examinations indicated a regular and significant increase in the prevalence after the summer period (years 1993 and 1994). Taking into consideration the individual hunting grounds in the area of Hradecko, the best situation was repeatedly found in its centre. Towards its verges it deteriorated.

The above-mentioned findings of seasonal dynamics in the disease prevalence was obtained in the only one, even though relatively large territory. The necessity to verify this knowledge repeatedly and the lack of information how the infestation would spread in independent hunting grounds made us to further study the problem in other two separated hunting grounds Luže and Blešno. The results achieved in these localities confirmed the findings obtained from Hradecko. The autumn extent of infestation corresponded approximately to the pre-treatment situation in the previous season, nevertheless also to the situation in the control (i.e. untreated) hunting grounds. However, in the separate grounds also the infestation intensity was slightly reduced as compared with the control group, which had not been more explicitly demonstrated in the area of Hradecko.

On the whole, the evaluation of IVM efficacy against bot fly larvae yielded highly positive results. The spring and summer prevalence as well as infestation intensity can be markedly reduced by this treatment. However, the parasitosis remains present in hunting grounds even after repeated therapy.

Generally, it can be stated that a very good efficacy of orally administered IVM was demonstrated against larval stages of bot fly disease. However, the biological aspects of the disease require to repeat the treatment annually.

\section{Účinnost perorálně podaného ivermektinu proti larvám hltanové střečkovitosti (Cephenemyia stimulator $\mathrm{C}$.) u srnčí zvěře}

Cílem 3 studií (jedna tříletá a dvě polovičního rozsahu) bylo ověřit účinnost dvoudenního zimního podání ivermektinu (dávka $0,3 \mathrm{mg} \cdot \mathrm{kg}^{-1}$ ž.hmotnosti a den) proti larvám střečka hltanového (Cephenemyia stimulator $\mathrm{C}$ ). Během všech experimentálních prací bylo vyšetřeno celkem 283 hlav srncủ (období odlovu 16. 5. - 31. 7) a srn i srnčat (období odlovu 1.9. - 31. 12.). Výskyt larev u srncủ byl zjištován při zpracovávání jejich trofejí. U holé zvěře byly nálezy larev pomocí výplachu nosních hlavových dutin. $Z$ nálezů byly vypočteny parametry extenzita a intenzita infestace pro pokusné honitby a $v$ roce 1994 pro honitby kontrolní (bez jakékoliv léčby). Bylo prokázáno, že účinkem zimního podání ivermektinu oba sledované parametry infestace $v$ porovnání $s$ předléčebnými nálezy význačně poklesly (nálezy u srncủ). V průběhu letního období však docházelo pravidelně $\mathrm{k}$ reinfekci zvěře, $\mathrm{tj}$. výraznému nárůstu extenzity a intenzity infestace (nálezy u holé zvěře). Opakování infekce bylo prokázáno jak v menším komplexu honiteb (celkově 7845 ha), tak i ve dvou samostatných honitbách (3850, resp. 1210 ha) z oblasti okresu Hradec Králové. Závěrem lze konstatovat, že ivermektin je vysoce účinným léčivem hltanové střečkovitosti srnčí zvěře. Biologické aspekty parazitózy však vyžadují (vzhledem k pravidelné reinfekci) každoroční opakování zimního ošetření zvěře.

\section{Acknowledgement}

The authors wish to thank Mrs. R. Uhrová for technical assistance throughout the study. 


\section{References}

CAMPBELL, W. C. 1989: Ivermectin and Abamectin. Springer Verlag, New York, 363 p.

ŠEVČ́KK B., KINKOROVÁ J., DANĚK J., STRAKOVÁ J., DVOŘ̉K M., LAMKA J. 1986: The development of a combined preparation containing rafoxanide and mebendazol for the control of parasitoses in hoofed game. Biol. chem. Vet. (Praha) 22:157-171

Address for correspondence:

Doc. RNDr. Jiří Lamka, CSc.

Department of Pharmacology and Toxicology

Pharmaceutical Faculty, Charles University

Heyrovského 1203

50005 Hradec Králové

Czech Republic

Phone: 420495235021

Fax: 420495210002

Email: lamka@faf.cuni.cz 